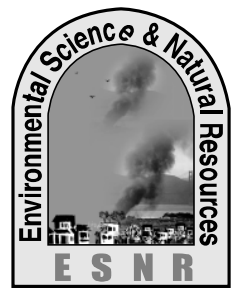

J. Environ. Sci. \& Natural Resources, 6(1): 41 - 45, 2013

ISSN 1999-7361

\title{
Effects of Boron Fertilization and Sowing Date on the Grain Protein Content of Wheat Varieties
}

\author{
J. N. Ferdoush and M. M. Rahman \\ Department of Soil Science \\ Bangladesh Agricultural University, Mymensingh-2202
}

\begin{abstract}
Wheat is the most important cereal crop and staple food of about two billion people around the world and contributes more calories and proteins to the world diet than any other cereal crop. Wheat grain quality is a function of grain composition, principally in proteins, which depends on the genotype and the environment. Protein content is a key quality factor that determines the suitability of wheat for a particular type of product as it affects other factors including mixing tolerance, loaf volume and water absorption capacity. The experiment was conducted at the Bangladesh Agricultural University farm during 2007 to 2010 to study the effects of boron fertilization and sowing dates on the Black point disease of wheat genotypes. The soil was silty loam in texture having $\mathrm{pH} 6.7$, cation exchange capacity $12.6 \mathrm{me} / 100 \mathrm{~g}$ soil, organic matter $1.9 \%$, total N $0.09 \%$, available $\mathrm{P} 7.3 \mathrm{ppm}$, exchangeable K $0.09 \mathrm{cmol} \mathrm{kg}^{-1}$, available S $12.4 \mathrm{ppm}$, available $\mathrm{Zn} 0.8 \mathrm{ppm}$ and available B $0.19 \mathrm{ppm}$. The wheat varieties used in the experiment were Prodip, Shatabdi and Sourav. Boron was applied @ 0 and $1 \mathrm{~kg}$ ha-1 and sowing dates were 18 November, 28 November, 08 December and 18 December. The experiment was laid out in a split-split plot design with a distribution of sowing dates to the main plots, varieties to the sub-plots and boron treatment to the sub-sub plots. All the factors were replicated three times. The total amount TSP, MoP, gypsum and zinc oxide were applied during final land preparation. Nitrogen was applied @ $120 \mathrm{~kg} \mathrm{ha}^{-1}$ from urea $(46 \% \mathrm{~N}), \mathrm{P} @ 20 \mathrm{~kg} \mathrm{ha}^{-1}$ from TSP $(20 \% \mathrm{P}), \mathrm{K} @ 60 \mathrm{~kg} \mathrm{ha}^{-1}$ from MoP $(50 \% \mathrm{~K}), \mathrm{S} @ 10 \mathrm{~kg} \mathrm{ha} \mathrm{from}^{-1}$ gypsum $(18 \% \mathrm{~S})$ and $\mathrm{Zn} @ 1.5 \mathrm{~kg} \mathrm{ha}^{-1}$ from $\mathrm{ZnO}(78 \% \mathrm{Zn})$. Urea was applied in three equal splits - final land preparation and 30 and 45 days after sowing. Boric acid $(17 \% \mathrm{~B})$ was applied to the B treatment plots prior to sowing. The crop was irrigated 2 times21 days (crown root initiation) and 47 days (heading stage) of sowing. Soil samples were analyzed for texture, $\mathrm{pH}, \mathrm{OM}$, total $\mathrm{N}$ and available P, K, S, Zn, S and B contents. The data were analyzed statistically (Gomez and Gomez, 1984). Boron application exerted a significant increasing effect on the protein content of wheat grain. A. significant variation in the $\mathrm{N}$ and protein content of wheat grains was observed among the wheat varieties in both the years. The 28 November sowing recorded the maximum protein content in wheat grains while the minimum value was noted with the 18 December sowing in both the years.
\end{abstract}

Key words: Boron, Protein, Sowing date, Wheat

\section{Introduction}

Wheat is the most important cereal crop and staple food of about two billion people around the world and is grown on more than 240 million hectares which is larger than for any other crop ( Safdar et al., 2009). World trade in wheat is greater than for all other crops combined. Wheat provides more nourishment for humans than any other food source. It is a major diet component because of the wheat plant's agronomic adaptability with the ability to grow from near arctic regions to equator, from sea level to plains of Tibet, approximately 4,000 m above sea level. In addition to agronomic adaptability, wheat offers ease of grain storage and ease of converting grain into flour for making edible, palatable, interesting and satisfying foods. Wheat protein is easily digested by nearly $99 \%$ of human population as is its starch. It also contains a diversity of minerals, vitamins and fats (lipids). With a small amount of animal or legume protein added, a wheat-based meal is highly nutritious.

Wheat grain quality is a function of grain composition, principally in proteins, which depends on the genotype and the environment. The genetic effect is mainly reflected by qualitative variation such as protein polymorphism and secondly by quantitative variation of total protein or of different units and subunits. In contrast, the environmental effect was mainly reflected by the quantitative variation, such as in total protein or protein unit and subunit contents. (Triboi et al., 2000).Protein composition is a key component of the end-use value for wheat grain. Although the qualitative composition of the grain is genetically determined, the quantitative composition is significantly modified by the growing conditions, and there are significant genotype $\times$ environment interactions (Jamieson et al., 2004)

The accumulation of the different protein fractions is highly asynchronous, inferring that the protein composition of the grain changes during grain development. One consequence is that conditions that shorten grain filling, such as high temperature or drought, affect the balance of protein fractions (Jamieson et al., 2001; Triboi et al., 2003). Protein content is a key quality factor that determines the suitability of wheat for a particular type of product as it affects other factors including mixing tolerance, loaf volume and water absorption capacity (Shah et al., 2008). Both protein quantity and quality are considered important in estimating the potential of flour for its end use quality (Farooq et al., 2001). 
The problem for growers is to improve grain yield while at the same time maintaining or improving grain protein content. Nitrogen is the key nutrient in the problem, since it is the nutrient used in greatest quantity by the growing wheat crop. It is central to the production of high yields and protein. The total protein content of wheat ranges from 6 to 22 percent, depending on soil, weather conditions, and variety. A protein content of 12 to 12.5 percent (on a moisturefree basis) can be considered as intermediate. The protein value will influence the grain's inclusion level in the diet and its value. In the international market place buyers are now demanding for wheat with higher protein content. Low yields and a decline in grain protein are a problem and a challenge for wheat growers today. Protein is an important component when selling wheat on a global market. Wheat is one of the world's most widely grown (and consumed) grains; Prices for wheat less than $11 \%$ protein may decline while process for wheat with relatively high protein may maintain current levels. Wheat cultivation in Bangladesh ranks next to rice. Its life cycle is shorter than to rice and is widely adapted to different agro-climatic conditions. Wheat is the most important stable food crop for more than one third of the world population and contributes more calories and proteins to the world diet than any other cereal crop (Abd-El-Haleem et al. 1998; Shewry, 2009). In addition to agronomic adaptability, wheat offers ease of grain storage and ease of converting grain into flour for making edible, palatable, interesting and satisfying foods.

Numerous studies on the response of wheat to B fertilizer have been reported in recent years including those from Bangladesh (Nyomora et al., 1997; Wang et al., 1999; Yan et al., 2003; Subedi et al., 1997; Rashid et al., 1997a, 1997b). Boron has a positive effect on the number of grains spike ${ }^{-1}$ and grain yield of wheat ( Hossain et al. 1994), number of spikelets on the main stem, leaf area, photosynthesis, 1000grain weight and N, P and $\mathrm{K}$ content of wheat ( Weo and Zuo, 1996). Wheat genotypes differ significantly in producing plant height, tillers plant ${ }^{-1}$, spikelets spike $^{-1}$, grains spike ${ }^{-1}$, weight of 1000-grain and straw yield under a given agro-climatic condition (Hasan, 1995).

In Bangladesh, the maximum grain yield is obtained from 15 November to 05 December sowing (Siddiqui et al., 2004; Shah et al., 2006)) and such a variation might be due to interaction of sowing date with local climatic variation (BARI, 1989). Late sowing leads to early maturity and reduction in yield attributes with resultant decrease in yield (Razzaque, 1982; BARI, 1986). Delay in seeding after 1 December resulted in yield loss@1\% per day in Bangladesh (BARI, 1986). Over $50 \%$ of the wheat grown in Bangladesh is planted in December (December 07-31) following delayed harvest of transplant aman paddy (Razzaque et al., 1994). Such late-sown wheat becomes affected by temperature during anthesis and / or grain filling period, resulting in low yields. The wheat yield would be highly affected if sowing is delayed after 01 December (Guler et al., 1986; Razzaque and Hossain,1991). Sowing date affect initiation of spike primordia (22-28 days after emergence), booting (3045 DAE), heading (40-58 DAE), grain filling and maturity of wheat (BARI, 1990).

\section{Materials and Methods}

The experiment was conducted at the Bangladesh Agricultural University farm, Mymensingh belonging to the Sonatola soil series of Noncalcareous Dark Gray Floodplain Soils under the AEZ-9: Old Brahmaputra Floodplain during 2007 to 2010. The soil was silty loam in texture having $\mathrm{pH}$ 6.7, cation exchange capacity $12.6 \mathrm{me} / 100 \mathrm{~g}$ soil, organic matter $1.9 \%$, total $\mathrm{N} 0.09 \%$, available P 7.3 ppm, exchangeable $\mathrm{K} 0.09 \mathrm{cmol} \mathrm{kg}^{-1}$, available S 12.4 ppm, available Zn 0.8 ppm and available B 0.19 ppm. The wheat varieties used in the experiment were Prodip, Shatabdi and Sourav . Boron was applied @ 0 and $1 \mathrm{~kg} \mathrm{ha}^{-1}$ and sowing dates were 18 November, 28 November, 08 December and 18 December. The experiment was laid out in a split-split plot design with a distribution of sowing dates to the main plots, varieties to the sub-plots and boron treatment to the sub-sub plots. All the factors were replicated three times. There were altogether $72(4 \times 3 \times 2 \times 3)$ unit plots, each plot measuring $5 \mathrm{~m} \times 4 \mathrm{~m}$. The total amount TSP, MoP, gypsum and zinc oxide were applied during final land preparation. Nitrogen was applied @ 120 $\mathrm{kg} \mathrm{ha}^{-1}$ from urea $(46 \% \mathrm{~N}), \mathrm{P} @ 20 \mathrm{~kg} \mathrm{ha}^{-1}$ from TSP (20\% P), K @ $60 \mathrm{~kg} \mathrm{ha}^{-1}$ from MoP (50\% K), S @ $10 \mathrm{~kg} \mathrm{ha}^{-1}$ from gypsum (18\% S) and Zn@ $1.5 \mathrm{~kg}$ $\mathrm{ha}^{-1}$ from $\mathrm{ZnO}(78 \% \mathrm{Zn})$. Urea was applied in three equal splits - final land preparation and 30 and 45 days after sowing. Boric acid $(17 \% \mathrm{~B})$ was applied to the $\mathrm{B}$ treatment plots prior to sowing. The crop was irrigated 2 times- 21 days (crown root initiation) and 47 days (heading stage) of sowing. The crop was harvested at maturity after about four months of sowing and the grains were analyzed for $\mathrm{N}$ treatment wise. Then the protein content of the wheat grains was calculated. The data were analyzed statistically (Gomez and Gomez, 1984). Soil samples were analyzed for texture, $\mathrm{pH}, \mathrm{OM}$, total $\mathrm{N}$ and available $\mathrm{P}$, $\mathrm{K}, \mathrm{S}, \mathrm{Zn}, \mathrm{S}$ and B contents.

\section{Results and Discussion}

The results in the Table 1 indicate that the application of boron significantly increased the grain nitrogen and protein content of wheat both in 2007-08 and 
2008-09. Protein content of the wheat grain in the boron treated plot was $13.45 \%$ in $2007-08$ and $14.31 \%$ in $2008-09$ while the corresponding values of untreated plot was $10.20 \%$ and $10.55 \%$, respectively. The $\mathrm{N}$ content of the wheat grain in 2007-08 and 2008-09 were $2.26 \%$ and $2.51 \%$ in the B treated plots while the corresponding values in the control plots were $1.79 \%$ and $1.85 \%$, respectively.A significant variation in the nitrogen and protein content of wheat grains was observed among the wheat varieties in both the years. The protein content of wheat grains in $2007-08$ ranged from $12.26 \%$ to $11.40 \%$ and that in 2008-09 ranged from $12.94 \%$ to $11.74 \%$.The variety Prodip recorded the maximum grain protein $(12.26 \%)$ in 2007-08 while the highest value in 2008-09 was noted with the variety Sourav (12.94\%).The variety Shatabdi recorded minimum grain protein in both the years. The $\mathrm{N}$ content in the grains of wheat varieties Pradip, Shatabdi and Sourav ranged from $2.00 \%$ to $2.15 \%$ in $2007-08$ and $2.06 \%$ to $2.27 \%$ in $2008-09$.

Table 1. Effects of boron, variety and sowing date on $\mathrm{N}$ and protein content of wheat grain

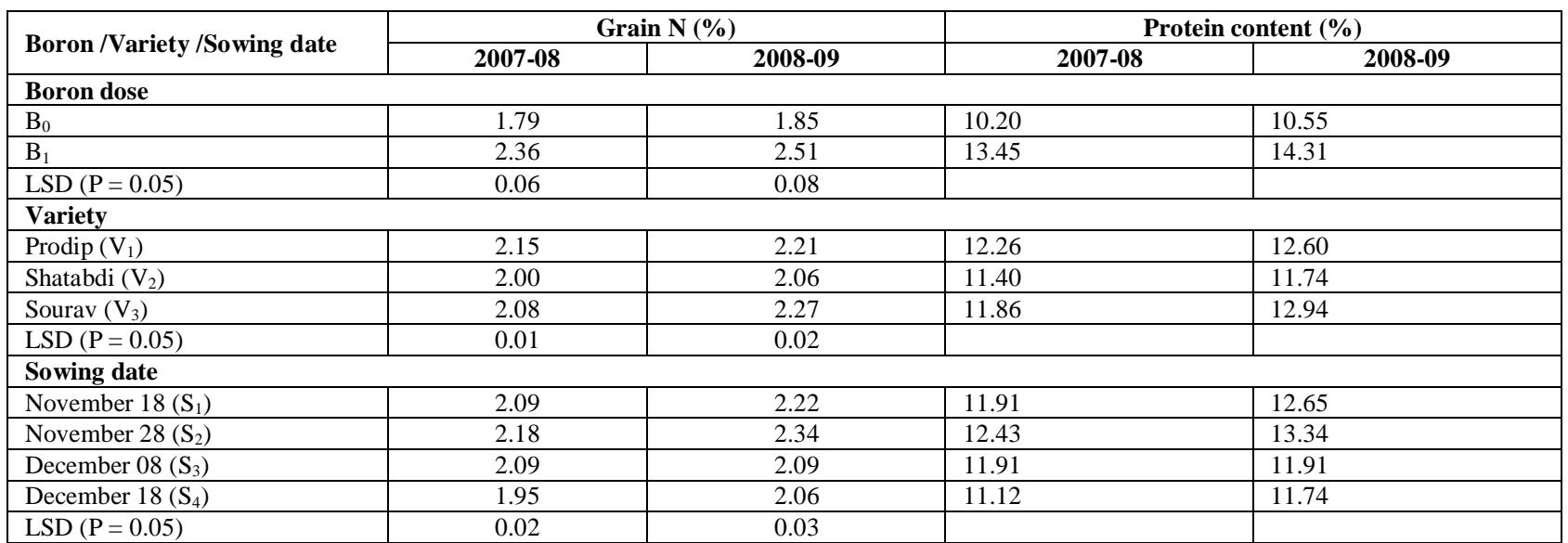

\section{$\mathrm{LSD}=$ Least significant difference}

Sowing date of wheat seed also influenced considerably the grain $\mathrm{N}$ and protein content of wheat in both the years. The grain protein content of wheat for 18 November, 28 November , 08 December and 18 December sowing ranged from $12.43 \%$ to $11.12 \%$ in $2007-08$ and $13.34 \%$ to $11.74 \%$ in $2008-09$. The 28 November sowing recorded the maximum protein content in wheat grains while the minimum value was noted with the 18 December sowing in both the years.
The protein content in wheat grains may be ranked in the order of 28 November $>18$ November $>08$ December $>18$ December sowing. The $\mathrm{N}$ content in wheat grains due to different sowing dates ranged from $1.95 \%$ to $2.18 \%$ in $2007-08$ and $2.06 \%$ to $2.34 \%$ in $2008-09$. In both the years, the 28 November sowing recorded the maximum $\mathrm{N}$ content in wheat grains and the minimum value was noted with the 18 December sowing.

Table 2. Interaction effects of boron $\times$ variety and boron $\times$ sowing date on $\mathrm{N}$ and protein content of wheat grain

\begin{tabular}{|c|c|c|c|c|}
\hline \multirow{2}{*}{ Interactions } & \multicolumn{2}{|c|}{ Grain N (\%) } & \multicolumn{2}{|c|}{ Protein content (\%) } \\
\hline & 2007-08 & 2008-09 & 2007-08 & 2008-09 \\
\hline \multicolumn{5}{|c|}{ Boron $\times$ Variety } \\
\hline $\mathrm{V}_{1} \mathrm{~B}_{0}$ & 1.89 & 1.83 & 10.77 & 10.43 \\
\hline $\mathrm{V}_{1} \mathrm{~B}_{1}$ & 2.40 & 2.58 & 13.68 & 14.71 \\
\hline $\mathrm{V}_{2} \mathrm{~B}_{0}$ & 1.71 & 1.74 & 9.75 & 9.92 \\
\hline $\mathrm{V}_{2} \mathrm{~B}_{1}$ & 2.29 & 2.38 & 13.05 & 13.57 \\
\hline $\mathrm{V}_{3} \mathrm{~B}_{0}$ & 1.78 & 1.97 & 10.15 & 11.23 \\
\hline $\mathrm{V}_{3} \mathrm{~B}_{1}$ & 2.39 & 2.56 & 13.62 & 14.59 \\
\hline $\operatorname{LSD}(\mathrm{P}=0.05)$ & NS & NS & & \\
\hline \multicolumn{5}{|c|}{ Boron $\times$ Sowing date } \\
\hline $\mathrm{S}_{1} \mathrm{~B}_{0}$ & 1.70 & 2.07 & 9.69 & 11.80 \\
\hline $\mathrm{S}_{1} \mathrm{~B}_{1}$ & 2.47 & 2.38 & 14.08 & 13.57 \\
\hline $\mathrm{S}_{2} \mathrm{~B}_{0}$ & 1.88 & 2.03 & 10.72 & 11.57 \\
\hline $\mathrm{S}_{2} \mathrm{~B}_{1}$ & 2.48 & 2.65 & 14.14 & 15.11 \\
\hline $\mathrm{S}_{3} \mathrm{~B}_{0}$ & 1.89 & 1.67 & 10.77 & 9.519 \\
\hline $\mathrm{S}_{3} \mathrm{~B}_{1}$ & 2.29 & 2.52 & 13.05 & 14.36 \\
\hline $\mathrm{S}_{4} \mathrm{~B}_{0}$ & 1.70 & 1.62 & 9.69 & 9.23 \\
\hline $\mathrm{S}_{4} \mathrm{~B}_{1}$ & 2.20 & 2.49 & 12.54 & 14.19 \\
\hline $\operatorname{LSD}(\mathrm{P}=0.05)$ & 0.05 & 0.05 & & \\
\hline
\end{tabular}

LSD=Least significant difference 
The interaction effects of boron $\mathrm{x}$ variety and boron $\mathrm{x}$ sowing date of wheat on the $\mathrm{N}$ and protein content of wheat grains were studied and a considerable variation was observed (Table 2). The grain $\mathrm{N}$ content due to boron $x$ variety interactions in 2007-08 ranged from $1.71 \%$ to $2.39 \%$ and that in $2008-09$ ranged from $1.74 \%$ to $2.58 \%$. The corresponding protein contents in wheat grains ranged from $9.75 \%$ to $13.68 \%$ and $9.92 \%$ to $14.71 \%$, respectively. The $\mathrm{N}$ content in the wheat grains due to boron $\mathrm{x}$ sowing date interactions ranged from $1.70 \%$ to $2.48 \%$ in $2007-08$ and $1.62 \%$ to $2.65 \%$ in $2008-09$ while the corresponding protein content in wheat grains ranged from $9.69 \%$ to $14.14 \%$ and $9.23 \%$ to $15.11 \%$, respectively.

\section{References}

Abd-El-Haleem, S. H. M.; Reham, M. A.; Mohamed, S. M. S.; abdel-Aal, E. S. M.; Sosulski, F. W. and Hucl, P. 1998. Origins, characteristics and potentials of ancient wheats. Cereal Foods World. 43: 708-715.

BARI. 1986. Bangladesh Agricultural Research Institute, Annual Report (1985-86), Joydebpur, Gazipur.

BARI. 1989. Bangladesh Agricultural Research Institute, Annual Report (1988-89), Joydebpur, Gazipur.

BARI. 1990. Bangladesh Agricultural Research Institute, A decade of Agronomic research abstract, Ed. A.B.M. Salahuddin and kazi Reazul Haque, BARI, Joydebpur.

Clarke, M. P.; Gooding, M. J. and Jones, S. A. 2004. The effects of irrigation, nitrogen fertilizer and grain size on Hagberg falling number, specific weight and black point of winter wheat. J. Sci. Food Agr., 84: 227-236.

Conner, R. L. and Whelan, E. D. P. 1989. Role of chromosome $5 \mathrm{~B}$ in controlling black point incidence in hard red spring wheat. Can. J. Plant Sci., 69 : 675-679.

Farooq, Z.; Rehman S. and Bilal, M. Q. 2001. Suitability of wheat varieties/lines for the production of leavened flat bread (naa). $J$. Res. Sci., 12: 171-179.

Guler, M.; Islam, N.; Siddique, A. B.; Anwar, M. and Chandra, N. 1986. Effect of seedling date on different wheat varieties. Abstracts of papers of Bangladesh Soc. Agron. Ann. Conf., BARI pp. 7-8.

Hossain, M. A.; Jahiruddin, M.; Hoque, M. S. and Ali, M.I. 1994. Effect of genotype and sowing date on the response to boron in wheat. Pakistan J. Sci. Indus. Res., 37(10): 432-435.

Jamieson, P. D.; Martre, M.; Samoil, V.; Porter, J. R.; Zyskowski, R. L.; Semenov, M. and Triboi, W. 2004. Modelling protein content and composition in wheat. In Proceedings of the $4^{\text {th }}$ International Crop Science Congress Brisbane, Australia, 26 Sep-1 Oct 2004.

Jamieson, P. D.; Stone, P. J.; Semenov, M. A. 2001. Towards modeling quality in wheat-from grain nitrogen concentration to protein composition. Aspects of Applied Biology, 64,111-126.

Kumar, J.; Schafer, P.; Huckelhoven, R.; Langen, G.; Baltruschat, H.; Stein, E.; Nagarajan, S. and Kogel, K. H. 2002. Bipolaris sorokiniana, a cereal pathogen of global concern: Cytological and molecular approaches towards better control. Mol. Plant Pathol., 3: 185-195.

Nymora, A. M. S.; Brown, P. H. and Freeman, M. 1997. Fall foliar-applied boron increases tissue boron concentration and nut set of almond. J. Amer. Soc. Hort. Sci., 122: 405410.

Rashid, A.; Rafique, E. and Alim, N. 1997. Micronutrient deficiencies in rainfed calacareous soils of Pakistan. II. Boron nutrition of peanut. Comm. Soil Sci. Plant Anal., 28: 149-159.

Razzaque, M. A. 1982. Wheat Production Manual. 1st Edn., BARI, Joydebpur, Bangladesh. pp 28103.

Razzaque, M. A. and Hossain, A. B. S. 1991. The wheat development program in Bangladesh. In: proceedings of wheat for the nontraditional warm areas. D.A. Saunders edt. UNDP/CIMMYT.

Razzaque, M. A.; Hossain, A. B. S.; Ahmed, S. M.; Sarkar, A. K. D.; Rahman, M. M.; Barma, C. D. and Amin, R. 1994. Wheat breeding strategies in the rice farming system of Bangladesh. In Wheat in Heat-stressed Environment: Irrigated, Dry Areas and Ricewheat farming System, DA Saunders, GP Hettel (eds). CIMMYT. pp. 239-249.

Sadasivaiah, R. S.; Perkovic, S. M.; Pearson, D. C.; Postman, B. and Beres, B. L. 2004. Registration of 'AC Meena' wheat. Crop Sci., 44 :697-698. 
Safdar, M. A.; Naseem, K.; Siddiqi, M. A.; Hameed, T. and Khalil, S. 2009. Quality evaluation of different wheat varieties for the production of unleavened flat bread (Chapatti). Pakistan J. Nutri., 8(11): 1773- 1778.

Shah, S. I. H., Siddiqui, K. A. Sahito, M. A. Tunio S. and Pirzada, A. J. 2008. Physico-chemical qualities and Nutritional attributes of stable bread wheat varieties representing diverse genetic origins. Sindh Univ Res. J., 40: 1-4.

Shah, W. A.; Bakht, J.; Ullah, T.; Khan, A. W. and Zubair, M. 2006. Effect of sowing dates on the yield and yield components of different wheat varieties. J. Agron., (1): 106-110.

Shewry, P. R. 2009. Wheat. J. Expt. Bot. 60(6):1537-1553

Siddiqui, M. H.; Oad, F. C.; Jamro, G. H. and Subhanm, F. 2004. Effect of planting time, planting density and weed control on the grain yield of bread wheat Mehran-89. Indus. J. Biol. Sci., 1(3): 188-191.

Subedi, K. D.; Budhathoki, C. B.; Subedi, M. and Yubak, D. 1997. Response of wheat genotypes to sowing date and boron fertilization aimed at controlling sterility in a rice-wheat rotation in Nepal. Plant Soil, 188(2): 249-256.

Triboi, E.; Martre, P. and Triboi-Blondel, A. 2003. Wnvironmentally-induced changes in protein composition in developing grains of wheat are related to changes in total protein content. Journal of Experimental Botany, 54 (388), 1713-1742.

Triboi, W.; Abad, A.; Michelena, A.; Lloveras, J.; Ollier, J. L. and Daniel, C. 2000. Environmental effects on the quality of two wheat genotypes. 1. quantitative and qualitative variation $\mathrm{f}$ storage proteins.

Wang, H.; Fernandez, M. R.; Mc Caig, T. N.; Gan, Y. T.; DePauw, R. M. and Clarke, J. M. 2003. Kernel discoloration and downgrading in spring wheat varieties in western Canada. Can. J. Plant Pathol., 25: 350-361.

Wang, Z. Y.; Tang, Y. L.; Zhang, F. S. and Wang, H. 1999. Effect of boron and low temperature on membrane integrity of cucumber leaves. J. Plant Nutri., 22:543-550.

Weo, X. M. and Zuo, D. F. 1996. The effect of rhizospheric boron dressing at the optimum concentration on the yield of winter wheat and the absorption of NPK nutrients. Beijing Agril. Sci., 14(4):21-24.

Williamson, P. M. 1997. Black point of wheat: in vitro production of symptoms, enzymes involved, and association with Alternaria alternate. Aust. J. Agric. Res., 48: 13-19.

Yan, H.; Li, W.; Guo,Y. and Liu, D. 2003. Effect of boron on carbohydrate assimilation and translocation in wheat. Acta Pedologica Sinica, 40(3): 440-445. 